Michał Przeperski

https://orcid.org/0000-0003-2712-5711

Instytut Historii Nauki Polskiej Akademii Nauk

\title{
Wymyślając wolnorynkowy leninizm. Dylematy ostatniego pokolenia komunistów na Węgrzech i w Polsce*
}

Zarys treści: Tekst stanowi próbę analizy politycznej aktywności i języka używanego przez dwóch reprezentantów ostatniego pokolenia komunistycznych polityków w Polsce i na Węgrzech. Jako przykładowi przedstawiciele tej generacji zostali potraktowani Miklós Németh oraz Leszek Miller. Celem wywodu jest rozpatrzenie podobieństw i różnic, potencjalnych wzajemnych przepływów idei i inspiracji, a w konsekwencji odsłonięcie nowych przestrzeni analitycznych, w ramach których można będzie sformułować nowe: pełniejsze i bardziej przekonujące hipotezy i tezy badawcze. Dotyczą one tak ostatnich lat funkcjonowania systemu komunistycznego, jak i punktu startu, z którego budowano nową, niekomunistyczną państwowość i nowy system społeczno-polityczno-ekonomiczny.

Abstract: The article analyses the political activities and the language used by two representatives of the last generation of communist politicians in Poland and Hungary: Miklós Németh and Leszek Miller. The text aims to examine similarities and differences, potential mutual flows of ideas and inspirations, and in consequence - to uncover new analytical fields within which researchers could formulate new, more complete and convincing research hypotheses and theses. They concern both the last years of the functioning of the communist system and the starting point of the new, non-communist statehood and new socio-political-economic system.

Słowa kluczowe: reforma, kryzys, transformacja ustrojowa, pieriestrojka, Leszek Miller, Miklós Németh, 1989

Keywords: reform, crisis, political system transformation, perestroika, Leszek Miller, Miklós Németh, 1989

\footnotetext{
* W niniejszym artykule zostały częściowo wykorzystane wyniki badań przeprowadzonych w ramach Visegrad Scholarship w Open Society Arichves w Budapeszcie przy wsparciu Uniwersytetu Środkowoeuropejskiego (Közép-Európai Egyetem; Central European University) w 2019 r. Tezy zaprezentowane $\mathrm{w}$ niniejszej pracy przedstawiają stanowisko autora, ale niekoniecznie stanowisko CEU.
} 
Historia transformacji ustrojowej w Europie Środkowej jest zdominowana przez narrację osnutą wokół historii intelektualistów, zwłaszcza tych będących spadkobiercami roku 1968, jak Adam Michnik czy János Kis. Nie kwestionując ich roli, wykazanej choćby w sytuujących się na pograniczu politologii oraz intellectual history pracach Davida Osta ${ }^{1}$, Vladimira Tismăneanu ${ }^{2}$ czy Piotra Wciślika ${ }^{3}$, chcę jednocześnie zwrócić uwagę na znaczenie komunistycznych polityków i spojrzeć na nich jako na podmiotowych współtwórców wydarzeń.

Co za tym idzie, za niezbędne uważam poważne potraktowanie ich rozmaitych wypowiedzi z końca lat osiemdziesiątych, w dotychczasowej literaturze zbyt często traktowanych jako polityczna mimikra czy pustosłowie. Wyjście poza dotychczasowe sposoby odczytywania ich działań w końcu lat osiemdziesiątych pozwoli jednocześnie na sformułowanie innych, bardziej przekonujących, szerszych diagnoz odnośnie do transformacji ustrojowej. Sądzę, że będą one skuteczniej tłumaczyć rzeczywistość, aniżeli te sformułowane lata temu w pracach Andrzeja Zybertowicza $^{4}$ czy Jadwigi Staniszkis ${ }^{5}$, a później konsekwentnie powielane np. przez Jerzego Targalskiego ${ }^{6}$. Te ostatnie, utrzymane w paradygmacie przekonania o silnej zakulisowej roli komunistycznych i postkomunistycznych służb specjalnych, można z dzisiejszej perspektywy potraktować raczej jako przedmiot badań aniżeli inspirujący poznawczo punkt odniesienia ${ }^{7}$.

Taki inspirujący punkt odniesienia można w moim przekonaniu odnaleźć w najnowszych badaniach z nurtu global history. Dwa lata temu na półki księgarskie trafiła książka 1989: A Global History of Eastern Europe autorstwa Jamesa Marka, Bogdana C. Iacoba, Tobiasa Rupprechta oraz Ljubicy Spaskovskiej. Autorzy tej ważnej, a nad Wisłą niestety niedostrzeżonej pracy, w centrum swojego zainteresowania umieścili dzieje społecznej i intelektualnej formacji, jaką stanowiły „elity transformacyjne”. Podkreślali jednocześnie, że składała się ona tak z reformatorsko nastwionych komunistów, jak i z części dawnych elit opozycyjnych ${ }^{8}$.

${ }^{1}$ D. Ost, Solidarność a polityka antypolityki, przeł. S. Kowalski, Gdańsk 2014.

${ }^{2}$ V. Tismaneanu, Wizje zbawienia. Demokracja, nacjonalizm i mit w postkomunistycznej Europie, przeł. H. Janowska, Warszawa 2000.

3 P. Wciślik, "Totalitarianism” and the Limits of Polish Dissident Political Thought. Late Socialistm and After, w: Thinking Through Transition. Liberal Democracy, Authoritarian Past, and Intellectual History in East Central Europe After 1989, red. M. Kopeček, P. Wciślik, Budapest 2015.

4 A. Zybertowicz, $W$ uścisku tajnych służb. Upadek komunizmu i układ postnomenklaturowy, Komorów 1993.

${ }^{5}$ J. Staniszkis, Postkomunizm. Próba opisu, Gdańsk 2001.

${ }^{6} \mathrm{~J}$. Targalski, Stużby specjalne i pieriestrojka. Rola służb specjalnych $i$ ich agentur $w$ pieriestrojce i demontażu komunizmu w Europie sowieckiej, t. 1-5, Warszawa 2017.

7 Por. P. Kowal, Mit „pokojowego przekazania władzy” a polityczny plan utrzymana wpływów PZPR, w: Sprzeczne narracje... z historii powojennej Polski 1944-1989, red. R. Spałek, Warszawa 2020, s. 373-389.

8 , at the centre of this book is the global history of the incremental, shuttering formation of what would in 1989 become 'transitional elites'. [...] These new elite networks were often made up of 
To spostrzeżenie stanowi dla mnie ważny punkt wyjścia. Przemiany, areną których stały się państwa Europy Środkowej w latach osiemdziesiątych, nie byłyby możliwe, gdyby nie reformatorsko nastawieni komuniści. Na poziomie strategicznych decyzji politycznych kluczowe było znaczenie sekretarza generalnego KC KZPR Michaiła Gorbaczowa, który w latach 1986-1987 niedwuznacznie zapalił zielone światło dla wielopłaszczyznowych reform, tak w ZSRR, jak i w kontrolowanych przez Moskwę krajach bloku. Natomiast praktyka polityczna współkształtowana była także przez tych reprezentantów lokalnych elit władzy, którzy byli przekonani do konieczności zmian systemu.

Komunistycznym politykom, zwłaszcza tym z ostatnich lat funkcjonowania systemu, odmawia się często motywacji ideowych, wskazując, że motorem do ich działania była raczej chęć zrobienia kariery, niż tworzenie nowego wspaniałego świata. Jakkolwiek jest to obserwacja trafna, to nie oznacza ona jednocześnie, że powinniśmy zrezygnować z analizy intelektualnych przemian, jakie przyniosły komunistom lata osiemdziesiąte. W niniejszym tekście pragnę odwołać się do doświadczeń politycznych dwóch postaci: Miklósa Németha oraz Leszka Millera. Pierwszy (ur. 1948) był w latach 1987-1988 sekretarzem Komitetu Centralnego Węgierskiej Socjalistycznej Partii Robotniczej, a w latach 1988-1990 ostatnim komunistycznym premierem Węgier (i jednocześnie pierwszym premierem Republiki Węgierskiej; od 23 października 1989 r.). Drugi był przez pewien czas wpływową postacią w drugim szeregu działaczy partyjnych, I sekretarzem KW w Skierniewicach, by zostać sekretarzem KC PZPR w grudniu 1988, a w 1989 r. stać się de facto drugą postacią w PZPR. Obaj byli młodymi gwiazdami, robiącymi karierę po linii partyjno-rządowej w ostatnich miesiącach funkcjonowania systemu komunistycznego.

Oprócz podobieństw były pomiędzy nimi ważne różnice. Miller określany był przez niektórych członków kierownictwa PZPR, nieco prześmiewczo, jako „prawdziwy orzeł z klasowym robotniczym rodowodem”, a współcześni historycy niebezzasadnie widzą w nim „ulubieńca aparatu” ${ }^{10}$. Miller rzeczywiście był aparatczykiem, podczas gdy Németh to raczej połączenie menadżera i intelektualisty: ekonomista, jeden z "chłopców z placu Dymitrowa”11, jak określano młodych ambitnych ekonomistów z Uniwersytetu Ekonomicznego w Budapeszcie. Jego błyskawiczne awanse określano w węgierskiej prasie jako „karierę ze snów"12, podczas gdy zagraniczna prasa najchętniej akcentowała jego prorynkowe poglądy ${ }^{13}$. Kluczowym podobieństwem, które moim zdaniem ostatecznie decyduje

both reforming Communists and former members of oppositions", J. Mark, B.C. Iacob, T. Rupprecht, L. Spaskovska, 1989: A Global History of Eastern Europe, Oxford 2019, s. 12.

9 W. Wiśniewski, Dlaczego upadł socjalizm? Od straszności do śmieszności, Toruń 2015, s. 177.

10 D. i T. Nałęcz, 1989-1990. Czas przełomu, Warszawa 2019, s. 126.

11 Zob. A. Antal, Chicago a Dimitrov téren. Neoliberalizmus és a Kádár-rendszer, Budapest 2021.

12 Szocialista álomkarrier. Interjú Németh Miklóssal, „Közgazdász” 23 III 1989.

13 G.P. Hefty, Sozailistischer Marktwirtschaftler, „Frankfurter Allgemeine Zeitung” 27 II 1988. 
o sensowności tego zestawienia, jest fakt, że obaj ci politycy musieli zderzyć się z sytuacją silnego kryzysu: politycznego, ekonomicznego, legitymizacyjnego. „Zostałem premierem w okresie charakteryzującym się głębokim kryzysem społeczno-ekonomicznym oraz ożywionym życiem publicznym"14 - mówił w wywiadzie dla polskiej prasy Németh. Miller mógłby powiedzieć dokładnie to samo o ostatnim okresie swojej działalności politycznej w szeregach PZPR.

\section{Od utopii do utopii}

Do anegdoty przeszła motywacja, jaka popchnęła Miklósa Németha do wstąpienia w szeregi aparatu partyjnego WSPR: miał on zdecydować się przyjąć posadę w gmachu KC przy placu Mari Jászai, gdy zorientował się, że nie jest w stanie utrzymać rodziny z pensji nauczyciela akademickiego ${ }^{15}$. $Z$ kolei dla Millera praca $\mathrm{w}$ aparacie partyjnym była jedną z nielicznych, wciąż funkcjonujących w systemie polskiego realnego socjalizmu dróg kariery i faktycznej poprawy statusu. Awans „od robotnika do sekretarza” pozostawał nieco zgrzebną, lecz rzeczywistą odmianą kariery od „pucybuta do milionera”, stanowiącej z kolei jądro mitu $\mathrm{o}$ „amerykańskim śnie” $\mathrm{w}$ jego wariancie zaabsorbowanym przez kulturę państw realnego socjalizmu.

Nie bez przyczyny nawiązuję do amerykańskich inspiracji i trudnego do przecenienia znaczenia, jakie miało oddanie pola przez socjalizm $\mathrm{w}$ walce o wyobrażenia i kreowanie ambicji jednostek. Odideologizowany reżim kadarowski na Węgrzech, nazywany komunizmem gulaszowym (gulyáskommunizmus) czy lodówkowym (fridzsiderkommunizmus), podobnie jak system stworzony przez Edwarda Gierka w Polsce, stanowił de facto system postrewolucyjny. Milenarystyczne przesłanie komunizmu jako systemu obiecującego wieczną szczęśliwość znalazło się na marginesie. Miejsce wielkiej idei zajął nacisk na realizację konkretnych ambicji, przede wszystkim osiągnięcie stabilizacji materialnej i, co za tym idzie, wewnętrzną petryfikację dotychczasowej struktury społecznej. W odniesieniu do Polski jako jeden z pierwszych na ten ostatni proces wskazywał Ireneusz Krzemiński ${ }^{16}$.

W efekcie, tak Németh, jak i Miller byli przedstawicielami pokolenia, które przeżywało socjalizację do życia publicznego $\mathrm{w}$ warunkach reżimów odideologizowanych, w których Związek Radziecki pozostawał punktem odniesienia gdy idzie o decyzje polityczne, ale w wielu innych aspektach porównywano się z Zachodem. Nie tylko jeśli mowa o sytuacji ekonomicznej, ale także jeżeli chodzi

14 Wyjście musimy znaleźć sami... „Życie” rozmawia z Miklosem Nemethem, premierem Wegier, „Życie Warszawy” 24-25 VI 1989.

15 A. Oplatka, Németh Miklós - Mert ez az ország érdeke, Budapest 2014, s. 94 n.

16 I. Krzemiński, System społeczny „epoki gierkowskiej”, w: Społeczeństwo polskie w kryzysie, red. S. Nowak, Warszawa 2004, s. 95-96. 
o efektywność pracy czy optymalizację systemów zarządzania. W tej perspektywie charakterystyczne jest, że w połowie lat siedemdziesiątych niespełna trzydziestoletni Németh spędził rok na stypendium w USA i to nie byle gdzie, ale na Uniwersytecie Harvarda ${ }^{17}$. W podobnym czasie taki sam pobyt w Ameryce zaliczył rówieśnik Németha, Leszek Balcerowicz ${ }^{18}$. Obaj ci ekonomiści złożyli do grobu realny socjalizm rozumiany jako system gospodarczy. Można dodać, że Leszek Miller - gdy w latach 2001-2004 sprawował funkcję premiera - zyskał sobie opinię polityka zdumiewająco prorynkowego, zwłaszcza jeżeli wziąć pod uwagę to, że pełnił ją jako lider partii samodefiniującej się jako socjaldemokratyczna.

Zbieżność późniejszych politycznych paralel karier obu polityków (po $1990 \mathrm{r}$. Németh był m.in. wiceprezesem Europejskiego Banku Odbudowy i Rozwoju) pozwala sformułować poszlakę, że o zwrot prorynkowy, proliberalny (a według coraz popularniejszej dziś normy językowej: neoliberalny) było znacznie łatwiej dzięki temu, że rynkowy kapitalizm od lat dla każdego z nich pozostawał pozytywnym punktem odniesienia. W szerszym ujęciu można bowiem potraktować zaangażowanie w tworzenie systemu komunistycznego, a następnie gorliwe burzenie go i budowanie systemu demokracji liberalnej, jako dwukrotne zaangażowanie $\mathrm{w}$ tworzenie swoistej utopii - choć o przeciwnych zwrotach ideowych ${ }^{19}$.

Chantal Delsol stwierdziła, że „w 1989 r. po raz pierwszy społeczeństwa totalitarne, zmierzające do tego, by zrealizować mit złotego wieku, poczuły się u kresu sił; zorganizowały antyutopijną rewolucję, która postawiła sobie za cel powrót do stanu przedutopijnego - mówiąc inaczej, powrót do rzeczywistego życia lub, jak twierdzą ich aktorzy, "powrót do historii»"20. Czy zatem, zgodnie z sugestią francuskiej autorki, powinniśmy patrzeć na rewolucje roku 1989 jako na faktyczne kontrrewolucje, a na ich aktorów jako na faktycznych konserwatystów? Gdy spojrzeć na ostatnie pokolenia komunistów jako na aktorów tych wydarzeń, można mieć poważne wątpliwości.

Wspomniany wcześniej Vladimir Tismăneanu oraz Ken Jowitt poświęcili w swoich pracach sporo miejsca rekonstrukcji leninizmu jako swego rodzaju struktury politycznego myślenia i działania, której istnienie przetrwało ponad rozpad światowego systemu komunistycznego ${ }^{21}$. Jednym z kluczowych wniosków, do jakich doszli, jest to, iż logicznym finałem istnienia i funkcjonowania leninizmu „jest całkowita eliminacja polityki, gdyż partia stanowi wcielenie bezwzględnej

17 A. Oplatka, op. cit., s. 93.

18 L. Balcerowicz, Trzeba się bić z PiS o Polskę, Warszawa 2016, s. 96-98.

19 J. Szacki, Liberalizm po komunizmie, Kraków 1994, s. 251-261.

${ }^{20}$ Ch. Delsol, Wprowadzenie do wydania polskiego, w: V. Tismăneanu, Diabet w historii. Komunizm, faszyzm i inne lekcje wieku dwudziestego, wprowadzenie Ch. Delsol, przeł. K. Michałowicz, Warszawa 2018, s. 11.

${ }^{21}$ V. Tismaneanu, Wizje zbawienia...; K. Jowitt, The New World Disorder. The Leninist Extinction, Berkeley 1992. 
woli zbiorowości”22. I choć z czasem - rok 1956 jest tu chyba najpewniejszą cezurą $\mathrm{w}$ dziejach światowego ruchu komunistycznego - system zrezygnował $\mathrm{z}$ masowego stosowania terroru, zniesienie polityki pozostało faktem. Z kolei w końcu lat siedemdziesiątych weteran Praskiej Wiosny Zdeněk Mlynář wskazywał, że ,jedynym uprawomocnieniem władzy totalitarnej jest ideologia, na której się opiera"23. Ale praktyka sprawowania władzy wskazywała, że jest inaczej - by powołać choćby fundamentalne studium Marcina Zaremby na temat legitymizacji nacjonalistycznej władzy komunistycznej w Polsce ${ }^{24}$. Innymi słowy polityka stawała się koniecznością i rzeczywistością, ale pozostawała trudno uchwytna, trudno nazywalna i nie było w pełni jasne, jak ma wyglądać. Plon tego przyszło zebrać w latach osiemdziesiątych.

Zmiany, które w Związku Sowieckim zainicjował Michaił Gorbaczow, podważyły ramy ortodoksji i tym samym wywołały chaos aksjologiczny. Ideowym totemem rządów Gorbaczowa stał się - dodajmy, że nie pierwszy raz w sowieckiej historii - powrót do korzeni, powrót do Lenina i leninizmu ${ }^{25}$. Rzecz jednak w tym, że faktyczna spuścizna Lenina, choć synkretyczna, była zupełnie nie do pogodzenia z pluralizmem czy też z wolnym rynkiem ${ }^{26}$. Sądzę, że w ten sposób powstały idealne warunki do przyjmowania kolejnej utopii. Miejsce komunistycznej, zajmowała utopia wolnego rynku.

\section{Nieliberalny wolny rynek}

Badania Györgya Földesa jasno pokazują, że do 1986 r., a więc niedługo po XIII Zjeździe WSPR, stało się jasne, iż przywódcy węgierscy nie dysponują narzędziami, które pozwoliłyby odwrócić negatywne tendencje w naddunajskiej ekonomice - przede wszystkim, gdy mowa o lawinowo narastającym zadłużeniu zagranicznym ${ }^{27}$. Oznaczało to, że cała ekipa Kádára znalazła się pod ścianą, a zmiany były nie li tylko opcją, ale niezbędną koniecznością. Jak z kolei podkreślał Zoltán Ripp, w klasycznym już dziele o transformacji ustrojowej na Węgrzech, rodząca się świadomość tego, w jak trudnej sytuacji znajduje się państwo, pociągnęła za sobą nastrój głębokiego - i bezprecedensowego - krytycyzmu ${ }^{28}$. Objął on

22 V. Tismăneanu, Diabeł w historii..., s. 119.

23 Zob. rozdział autorstwa Mlynářa w: Communist Reformation. Nationalism, Internationalism, and Change in the World Communist Movement, red. G.R. Urban, New York 1979.

${ }^{24}$ M. Zaremba, Komunizm, legitymizacja, nacjonalizm. Nacjonalistyczna legitymizacja władzy komunistycznej w Polsce 1944-1980, Warszawa 2005.

25 W. Taubman, Gorbachev. His Life and Times, New York 2017.

${ }^{26}$ V. Tismăneanu, Diabeł $w$ historii..., s. 149-151.

27 G. Földes, Az eladósodás politikatörténete, 1957-1986, Budapest 1995.

28 Z. Ripp, Rendszerváltás Magyarországon 1987-1990, Budapest 2006, s. 27 n. 
z jednej strony część inteligencji, a z drugiej - zdynamizował ruchy odśrodkowe $\mathrm{w}$ aparacie partii i państwa, stymulując tym samym walkę o władzę.

Jednym $\mathrm{z}$ węgierskich dyskursywnych, propagandowych - i w pewnej mierze operacyjnych - narzędzi do opanowywania kryzysu ekonomiczno-społecznego w latach 1987-1989 stał się program reform politycznych określany jako gazdasági-társadalmi kibontakozás programja (pol. program ekonomiczno-społecznego odrodzenia) lub po prostu kibontakozás. Miklós Németh był jedną z twarzy tego programu, prezentującą ją w popularnych węgierskich mediach ${ }^{29}$. Na marginesie można zresztą dodać, że również w Polsce w tym czasie media pełne były dyskusji o tzw. drugim etapie reformy gospodarczej, który musiał radzić sobie z problemami zbliżonymi do węgierskich, różniąc się przede wszystkim bardzo poważnym zadłużeniem zagranicznym ${ }^{30}$.

Przedstawiając idee stojące za programem kibontakozás, Németh mówił: „rynki - rynek zewnętrzny, ale także rynek krajowy - powinny wybierać te elementy ze sfery węgierskiej produkcji, których świat potrzebuje"31. Nie pozostawiał tym samym wątpliwości, że to rynek - w tym ten globalny - ma stanowić kluczowy mechanizm regulacyjny gospodarki. Miało to za sobą w oczywisty sposób pociągnąć likwidację monopoli i szeroko zakrojoną liberalizację. Jednocześnie jednak młody sekretarz KC WSPR podkreślał, że „takie stanowisko nie tylko nie osłabia, ale raczej wzmacnia odpowiedzialność i zadanie centralnego planowania gospodarczego oraz, generalnie, rolę pracy organów rządowych"32. Tego rodzaju enuncjacje interpretuje się często jako chęć zastosowania tzw. modelu chińskiego, czyli autorytarnej, skokowej modernizacji prorynkowej łączącej liberalizację gospodarczą z utrzymaniem pełni kontroli politycznej nad gospodarką. Jest to jednak, jak sądzę, zbyt daleko idące uproszczenie.

Kibontakozás miał bowiem także komponent polityczny. „Jestem przekonany, że jeśli reforma będzie konsekwentnie kontynuowana, a w tej sytuacji nie mamy innego wyjścia, jeśli pieniądze zostaną postawione w gospodarce tak, aby selekcjonowały i integrowały różne interesy; jeśli samodzielność i odpowiedzialność przedsiębiorstwa oraz wszystkie tego konsekwencje zaczną funkcjonować w należyty sposób; jeśli w maksymalnym stopniu wciągniemy zainteresowane strony $\mathrm{w}$ decyzje dotyczące naszych programów, w istotnych kwestiach dotyczących całego naszego społeczeństwa; jeśli zatem zapewnimy większą otwartość społeczną; gdy prowadzimy dialog [...] ludzie czują, że mają zadanie; jeżeli jednostki wiedzą, co robić i dlaczego; wówczas, jestem przekonany, że nasze społeczeństwo

\footnotetext{
${ }^{29}$ Np. Németh Miklós, az MSZMP KB titkára a Hírháttérben, „Magyar Nemzet” 4 VII 1987.

30 D.T. Grala, Reformy gospodarcze w PRL (1982-1989). Próba uratowania socjalizmu, Warszawa 2005.

31 OSA HU 300-40-5, Box 141, Miklós Németh discusses economic-social resurgence, Budapest TV service in Hungarian, 4 VII 1987, s. 9.

${ }^{32}$ Ibidem.
} 
i nasi obywatele nadal będą skłonni do tymczasowych poświęceń, abyśmy mogli stworzyć warunki lepszej i śmiem twierdzić, szczęśliwszej przyszłości. To również oznacza demokrację, odnowę naszych instytucji”33. Umieszczony na końcu tak długiej wyliczanki komponent „demokratyzacyjny” z pewnością nie miał kluczowego znaczenia - ale nie należy go lekceważyć.

Można je natomiast rozumieć różnorako. Uważam, że warto podkreślić fakt, iż „demokratyzacja” stanowiła niezbędny element swoistej „nowej rewolucyjności”, którą zadekretował i w pierwszych latach swoich rządów starał się konsekwentnie promować Gorbaczow ${ }^{34}$. Z czasem zresztą retoryka polityczna zyskiwała na znaczeniu, stając się faktem politycznym per se, wpływającym na nastroje społeczne oraz działanie aparatu państwa. We wrześniu 1987 r. Németh stwierdzał, że bez reformy systemu instytucjonalnego nie da się wyobrazić sobie szybkiego postępu zmian ${ }^{35}$, a w programowym tekście dla partyjnego organu „Népszabadság” w siedemdziesiątą rocznicę rewolucji październikowej wskazywał, że sukces uda się odnieść tylko we współpracy z ZSRR i całym obozem komunistycznym $^{36}$. Czy jednak to wszystko pozwala już mówić o liberalnej utopii? Naturalnie, nie. Co najistotniejsze, węgierski polityk odżegnywał się stanowczo od liberalizmu.

W tekście z bożonarodzeniowego numeru dziennika "Magyar Nemzet” wybrzmiewały akcenty antyliberalne: ,jest to zadanie o wymiarze historycznym, ponieważ żadne społeczeństwo nigdy nie mogłoby harmonijnie rozwinąć korzyści płynących z indywidualnej autonomii, samorealizacji i sprawiedliwości społecznej. Liberalny pogląd, że interes własny automatycznie kieruje ludzi ku temu, by jak najlepiej służyli interesowi społecznemu, został zdyskredytowany. Liberalizm, poprawiając wyniki ekonomiczne, generuje egoizm, który dezorganizuje społeczeństwo i relacje międzyludzkie. Nie możemy podążać tą drogą" ${ }^{37}$. Co ciekawe, nie zabrakło w nim również elementów, które można uznać za paternalistyczne w duchu, o którym wspomniałem wcześniej. „Powinniśmy promować instytucję rodziny, aby było mniej urazów moralnych i psychicznych oraz niepowodzeń $\mathrm{w}$ integracji. Wpływają one nie tylko na procesy reprodukcji społecznej, ale także ograniczają chęć i zdolność do pracy"38. Promowanie rozwiązań silnie prorynko-

\footnotetext{
33 Ibidem, s. 13.

${ }^{34}$ M. Gorbaczow, Przebudowa i nowe myślenie dla naszego kraju i dla całego świata, przeł. A. Karkus et al., Warszawa 1988.

35 „A politikai intézményrendszer reformja nélkül nem képzelhető el gyors előrelépés”, A bizalom csak eredményes politika bázisán teljesedhet ki, „Magyar Nemzet” 17 IX 1987.

36 „A kibontakozás egyedül nem járható végig. Új típusú összefogás szükséges a Szovjetunióval, a szocialista országokkal, a forradalmi munkáspártokkal és az egész baloldali világmozgalom különböző erőivel”, Megújulás, reform, társadalom, „Népszabadság” 7 XI 1987.

37 „Magyar Nemzet” 24 XII 1987.

${ }^{38}$ Ibidem.
} 
wych jeszcze wiosną 1988 r. było w jego wypowiedziach zrównoważone poprzez opiewanie „solidarności socjalnej”39.

Ważnym wątkiem obecnym na Węgrzech, a praktycznie nieobecnym nad Wisłą, było odwoływanie się do reformatorskich tradycji systemu komunistycznego, wiążących się z początkiem funkcjonowania tzw. Nowego Mechanizmu Ekonomicznego (węg. új gazdasági mechanizmus) ${ }^{40}$. „W 1968 r. wraz z reformą systemu zarządzania gospodarczego rozpoczął się drugi Czas Reform [pierwszy, węg. Reformkor, przypadł na lata 1825-1848 - M.P.] w historii naszej Ojczyzny. Do tej pory reforma gospodarcza jest żywą historią. Nasza polityka reform wzbudziła zainteresowanie na świecie: jesteśmy szanowani za naszą politykę rolną, spółdzielczą, narodowościową oraz wobec Kościołów. Musimy trwać przy ideałach reformy $\mathrm{w}$ trudnych czasach. Musimy zmobilizować twórcze, aktywne siły społeczeństwa i dostosować system instytucji politycznych do tego zadania". W ocenie Németha niezbędna była realistyczna polityka, stanowiąca jednocześnie element kontynuacji: „Musimy wzmocnić demokrację socjalistyczną, budując na istniejących fundamentach, toczyć walkę na dwóch frontach z konserwatystami i pseudoodnowicielami oraz z nieodpowiedzialną demagogią" ${ }^{11}$. Również i w tym wypadku próbował on godzić ogień z wodą. W praktyce sekretarz KC domagał się „rewolucyjnego realizmu” oraz „ciągłości w zmianach”, a to ostatnie hasło do złudzenia przypominało bezlitośnie obśmiewane nad Wisłą hasło o „partii tej samej, lecz nie takiej samej”, podniesione po pierwszej części X Plenum KC PZPR w grudniu $1988 \mathrm{r}$.

Debaty intelektualne $\mathrm{z}$ końca lat osiemdziesiątych miały wiele wspólnego z tymi prowadzonymi dwie dekady wcześniej, w latach sześćdziesiątych. Od połowy tej ostatniej dekady stosunkowo liberalny ekonomicznie system węgierski przeżywał swoje upadki (m.in. odsunięcie jego twórcy, Rezső Nyersa w 1974 r., i związane z tym przykręcenie śruby ${ }^{42}$ ), lecz funkcjonował aż do końca komunistycznych Węgier, stanowiąc o ich odmienności w ramach całego bloku. Z punktu widzenia praktyki ekonomicznej oznaczało to, że całe pokolenie Węgrów zostało zsocjalizowane do funkcjonowania w systemie gospodarczym, w którym rola swoiście pojmowanej prywatnej inicjatywy, a także regulacyjna funkcja rynku stanowily normę. Z punktu widzenia intelektualnego oznaczało to z kolei, że Németh wywodził się ze szkoły ekonomicznej, w której rozumowanie kategoriami rynkowymi

\footnotetext{
39 Reformeszmék a nehéz időkben is, „Magyar Hírlap” 5 IV 1988.

${ }^{40}$ M. Przeperski, Historia pewnego przystosowania. Wegrzy lat sześćdziesiątych w raportach Departamentu Badania Stuchalności Radia Wolna Europa, w: Opozycja i opór społeczny w Polsce po 1956 roku, red. J. Olaszek, T. Kozłowski, Warszawa 2011, s. 219-239.

${ }^{41}$ Reformeszmék a nehéz időkben is, „Magyar Hírlap” 5 IV 1988.

42 J.M. Rainer, János Kádár (1912-1989). Die letzte Generalsekretär der ungarischen Kommunisten, w: Die letzten Generalsekretäre Kommunistische Herrschaft im Spätsozialismus, red. M. Sabrow, S. Schattenberg, Berlin 2018, s. 79.
} 
było standardem, niestanowiącym w żadnej mierze nowinkarstwa - a tak należałoby scharakteryzować sytuację np. w ZSRR. Tutaj też warto dostrzec podobieństwa między Polską a Węgrami. Na ulokowane w debatach lat sześćdziesiątych głębokie korzenie liberalnego zwrotu w polskim myśleniu o ekonomii zwracał uwagę np. Miklós Mitrovits ${ }^{43}$. W tym sensie na analizowane przeze mnie procesy można patrzeć jako na kontynuację znacznie dłuższych trendów, możliwych do zaobserwowania nie tylko w Polsce czy na Węgrzech, ale w skali globalnej ${ }^{44}$.

\section{Odsłaniając karty}

Nie ma wątpliwości co do tego, że względy taktyczne, chęć osiągnięcia konkretnych, krótkoterminowych korzyści politycznych, miały poważne znaczenie dla tego, jak ostatecznie kształtowała się sytuacja polityczna: tak nad Wisłą, jak i nad Dunajem. Oto np. radykalizm Németha zyskał na sile po odsunięciu od władzy Jánosa Kádára w maju 1988 r. Efektywnie przekreślił on wówczas wiele ze swoich wcześniejszych poglądów, stwierdzając np.: „głosiliśmy politykę reform, która sięgnie aż do fundamentów [...], [ale] rozwiązania pozostały tylko na papierze". Coraz otwarciej wskazywał, że inspiracja do węgierskich przemian nie płynie ze Wschodu, lecz z Zachodu. „Musimy bardziej dostosować się [...] do Europejskiej Wspólnoty Gospodarczej”"45 - mówił w wywiadzie dla „Magyar Hírlap” w maju 1988 r. W dziewięć miesięcy później szedł dalej, mówiąc, że „nie ma powodu, aby nie dyskutować o wstąpieniu Węgier do Europejskiego Stowarzyszenia Wolnego Handlu" 46 . Bardzo otwarcie mówił o tym, że fundamentalne problemy socjalizmu powinny zostać na nowo przemyślane ${ }^{47}$. Był to niewątpliwie kierunek silnej otwartości na Zachód. W wystąpieniu w dzień przyjęcia funkcji premiera wyliczył filary, na których powinien oprzeć się program odrodzenia: „Te filary to współczesne państwo prawa; [...] specyficzna rola kraju, która opiera się na sile sojuszu węgiersko-sowieckiego i na naszych otwartych stosunkach z Zachodem; socjalistyczna gospodarka rynkowa, konkurencja, która wymusza produkcję skupiającą się na jakości; nasza zdolność do odnowy; nasza gotowość do przyjęcia ducha przedsiębiorczości; stopniowo oddolnie tworzony system ustanawiania socjalistycznego pluralizmu, w którym ucieleśnia się szlachetna konkurencja polityczna; relacje społeczne oparte na wartościach solidarności społecznej; i społeczne

\footnotetext{
${ }^{43}$ M. Mitrovits, Az önigazgatás bukása. A neoliberális rendszerváltás Lengyelországban, „Eszmélet” 2009, nr 83.

44 A. Leszczyński, Skok w nowoczesność. Polityka wzrostu w krajach peryferyjnych 1943-1980, Warszawa 2013.

45 Nem dönthetünk a nép háta mögött, „Magyar Hírlap” 28 V 1988.

46 OSA HU 300-40-5, Box 141, Nemeth says EFTA, neutrality are worth considering, 14 II 1989.

47 Újra kell gondolni a szocializmus alapkérdéseit, „Magyar Hírlap” 13 IX 1988.
} 
zrozumienie" $^{48}$. Nieledwie zrównanie otwartości wobec Zachodu z braterskimi relacjami z ZSRR było, jak się wydaje, kolejnym znakiem ewolucji poglądów wyrażanych przez Németha. Co wreszcie najbardziej niezwykłe, poglądy wyrażane przez polityka komunistycznego pro foro interno oraz za granica przestały się od siebie różnić. W wywiadzie dla „Newsweeka”, Németh, zapytany o to, jakie Węgry chciałby widzieć za pięć lat, odpowiedział: „mam nadzieję, że będzie to gospodarka zorientowana na rynek, promująca indywidualną aktywność, miejsce, w którym ludzie mają większą pewność siebie i pokładają większe zaufanie w przyszłość"49.

Jak bumerang wracało jednak pytanie: kto zapłaci za reformy? Kilka dni po wprowadzeniu znaczących podwyżek cen, do czego doszło 9 stycznia 1989 r., Németh przemawiał do robotniczych aktywistów partyjnych. Po raz kolejny pokazał wówczas twarz twardego liberała: „rząd jest chętny do współpracy z organizacjami alternatywnymi [eufemizm oznaczający niezależne partie polityczne - M.P.], a także z ruchem związkowym. Oferuje współpracę alternatywnym organizacjom na rzecz odnowy socjalizmu dla faktycznego urzeczywistnienia humanizmu i wartości społecznych. Z drugiej strony, rząd nie sprzymierzy się z siłami zachowawczymi, które odmawiają historycznego prawa do istnienia socjalizmu, które mają liberalne lub prymitywnie egalitarne komunistyczne złudzenia"50.

Prymitywnie egalitarne iluzje komunistyczne - to retoryka ostrzejsza od tej, jaką stosował w tym samym czasie niezwykle popularny w Polsce minister przemysłu Mieczysław Wilczek, znany przecież z ciętego języka. Z pewnością mógłby się on jednak podpisać pod wieloma ocenami Németha. „Biurokratyczny, nadmiernie scentralizowany model socjalizmu, budowa [...] socjalizmu znalazła się w impasie” - mówił ten ostatni na początku marca 1989 r. „Zawsze popełnialiśmy błędy, gdy braliśmy modele zewnętrzne za przykład do naśladowania"51 - tłumaczył, wyjaśniając jednocześnie, dlaczego Węgry nie mają zamiaru imitować żadnych innych gotowych rozwiązań politycznych i gospodarczych. Sęk jednak w tym, że wszystkie działania Németha prowadziły ku niczemu innemu, jak maksymalnemu zbliżeniu się do modelu zachodniej gospodarki rynkowej. Rzeczywista wiara w możliwość pójścia trzecią drogą - daleką od ortodoksji komunistycznej, a niebędącej drogą kapitalistyczną - była jednak zupełnie minimalna.

Na tym tle nie tak dawno liderujący jeszcze Węgrom János Kádár był dla premiera absolutnym dinozaurem. „Kádár był zagorzałym przeciwnikiem szerokiego rozpowszechniania informacji, które mogłyby zaniepokoić opinię publiczną"52,

48 OSA HU 300-40-5, Box 141, Nemeth interviewed on new position, Budapest TV broadcast, 24 XI 1988.

49 Reform is 'irreversible', „Newsweek” 12 XII 1988.

50 OSA HU 300-40-5, Box 141, Nemeth addresses party activists, Budapest TV broadcast, 14 I 1989.

51 OSA HU 300-40-5, Box 141, Premier says state socialism deadlocked, 9 III 1989.

52 R.L. Tőkés, Hungary's Negotiated Revolution. Economic Reform, Social Change and Political Succession, Cambridge 1996, s. 271. 
wskazywał w latach dziewięćdziesiątych węgierski badacz Rudolf L. Tőkés. Németh natomiast, wprost przeciwnie, na każdym kroku podkreślał konieczność działania przy otwartych drzwiach. Wspierający się na biurokracji Kádár musiał zgrzytać zębami, czytając główny partyjny organ „Népszabadság” w ostatni dzień 1988 r. Mógł tam przeczytać, że premier „jest przywiązany do takiego modelu rządu, który łamie ramy hierarchicznej biurokracji poprzez demokratyczne podejście do wiedzy"53. Z jednej strony, jak na ospałe węgierskie warunki, był to głos ostry. $\mathrm{Z}$ drugiej strony jednak, nie był niczym innym jak powieleniem pomysłu gorbaczowowskiej glasnosti, od kilku lat odmienianej przez przypadki w mediach całej Europy - tak wschodniej, jak i zachodniej.

Ten ostatni kontekst należy w moim przekonaniu sumiennie przywoływać za każdym razem, gdy mówimy o szerzej rozumianej ewolucji dyskursywnej i światopoglądowej w końcu lat osiemdziesiątych. Był to czas, w którym nie tylko pojedynczy aktorzy w ramach istniejącego układu odniesień zmieniali swoje zapatrywania i mówili o tym głośno. Sprzyjała temu dramatyczna porażka socjalizmu jako projektu modernizacyjnego. Symboliczne były nieudolne próby ocenzurowania w krajach bloku Trzeciej fali Alvina Tofflera, biblii społeczeństwa informacyjnego, wykazującej nieinnowacyjność i kruchość reżimów socjalistycznych. Wreszcie, co chyba najistotniejsze, granice tego, co dopuszczalne w oficjalnym obiegu w krajach komunistycznych, bezprecedensowo się poszerzyły. Nabolałe sprawy w krajach bloku, gdy zostały nazwane, zmieniły swój charakter. Stały się faktami społecznymi, których nie dawało się zignorować.

\section{Język a praktyka polityczna}

To, co napisałem powyżej, pozwala dostrzec w Némecie reformatora, który jednak swój radykalizm odsłaniał stopniowo - w zależności od zmiennych koniunktur politycznych. „Co do odwagi, jeżeli chodzi o proces reformowania, Németh w tym okresie reprezentował dość wysoki poziom. Licząc w skali od jednego do dziesięciu, sytuował się w granicach osiem, dziewięć. Był już zaawansowanym reformatorem" ${ }^{4}$ - po dekadzie oceniał węgierskiego premiera Władysław Baka, również ekonomista, w owym czasie członek Biura Politycznego KC PZPR. Kategoria „reformatora” była z polskiej perspektywy kluczowa, ona też wrosła w polską kulturę dyskutowania o przełomie roku 1989.

Jej zdefiniowanie nie jest jednak takie proste. Jako nowa, wschodząca gwiazda na partyjnym firmamencie, o taką definicję zapytany został w końcu grudnia 1988 r. Leszek Miller. „Dla mnie to jest... działanie plus decentralizacja. Działanie,

53 „Népszabadság” 31 XII 1988.

${ }^{54}$ Polska 1986-1989. Koniec systemu, t. 2: Dyskusja, red. A. Paczkowski, Warszawa 2002, s. 104 (głos Władysława Baki). 
dlatego że za dużo tracimy czasu na projektowanie nowych rozwiązań, oczekiwanie tych rozwiązań, fascynujemy się tym, a zbyt mało wykorzystujemy te warunki, które już istnieją. A więc - za mało działamy. [...] Natomiast decentralizacja rozumiana $\mathrm{w}$ sposób, iż nie może to być akt łaski, akt łaski centrum w stronę terenu, a musi to być podstawowy warunek umożliwiający przemiany społeczne polityczne i gospodarcze w kraju. Tutaj musimy iść znacznie bardziej głęboko"55. „Działanie plus decentralizacja” - to dość nieporadna próba parafrazy leninowskiej definicji, głoszącej, że komunizm to „władza rad plus elektryfikacja”. Stanowi jednocześnie znakomity symbol epoki: decentralizacja to przecież nic innego jak radykalne zakwestionowanie praktyki politycznej totalitarnego (u swego zarania) państwa, którego twórcą był nie kto inny jak parafrazowany Lenin. To paradoks w sensie ścisłym.

Leszek Miller w niewielkim jedynie stopniu zajmował się ekonomią i jego wypowiedzi na ten temat są niezwykle lapidarne. Z perspektywy ćwierćwiecza wskazywał, że w 1989 r. polska gospodarka „nie tyle runęła, ile rozpoczęła proces rynkowej transformacji. Przyszłość miała mieć charakter powolnego, ale konsekwentnego wkraczania w system demokracji parlamentarnej oraz w świat mechanizmów rynkowych. Ale z gwarancjami stabilności państwa i nastrojów społecznych oraz bezpieczeństwa dla wszystkich uczestników tego procesu. Bez żadnego szoku, z mechanizmami korekcyjnymi" ${ }^{56}$. To słowa nie tylko pochodzące od niespecjalisty, ale również próbujące po latach nadać wydarzeniom nieco nowy wymiar. Katastrofa gospodarcza Polski była bowiem w końcu lat osiemdziesiątych dojmująca, natomiast rozwiązania proponowane przez Millera pozostawały pobożnymi życzeniami. Już w 1988 r. miał on zresztą jasno mówić, że „ten system [tj. komunizm] idzie nieubłaganie na dno" 57 . Jednak dylemat: ile kapitalistycznych rozwiązań w socjalizmie, Miller rozwiązywał podobnie jak Németh. Werbalnie obaj przez długi czas byli poszukiwaczami „trzeciej drogi”: „Czegoś, co nie byłoby dawnym socjalizmem, ale też nie byłoby kapitalizmem”58.

O ile w wypadku Németha możemy mówić o jego znajomości praxis zachodniej polityki, o tyle u Millera więcej było intuicji i raczej znajomości „języka Zachodu”. To zaś zdaje się potwierdzać wcześniejszą moją tezę, iż nowy aparat pojęciowy fundamentalnie przebudowywał nie tylko rzeczywistość dyskursów politycznych, ale także wpływał na tworzenie nowych faktów społecznych. W styczniu 1989 r. na drugiej części X Plenum KC, decydującego dla przemian w Polsce, Miller mówił: „W dyskusji nad kształtem partii, jej organizacyjnej i ideowej formuły, coraz częściej pojawia się pojęcie społeczeństwa obywatelskiego. Znajduje ono pełnoprawne miejsce w wizji ładu społecznego polskiego socjalizmu przełomu

55 „Dziennik Telewizyjny” 30 XII 1988.

56 L. Miller, Anatomia siły. Rozmowa z Robertem Krasowskim, Warszawa 2013, s. 11.

57 M.F. Rakowski, Dzienniki polityczne 1987-1990, Warszawa 2005, s. 187 (13 V 1988).

58 W. Wiśniewski, op. cit., s. 199. 
tysiąclecia. Przemiany społeczne, jakie zachodzą w otoczeniu partii, wymagają głębszej refleksji. Dotychczasowe nasze doświadczenia reformatorskie dotyczą bowiem bardziej sfery gospodarki i systemu politycznego" 59 . Trudno zaprzeczyć, że były to trafne obserwacje, ale wypływały z nich wnioski miażdżące dla przyszłości systemu.

Németh zajmował się gospodarką i miał przynajmniej w pewnej mierze plan na jej reformę, który wspierał się na dość powszechnym przekonaniu - o czym pisała m.in. Johanna Bockman ${ }^{60}$ - że skuteczna przebudowa systemowa krajów komunistycznych traktowana była jako rzecz zupełnie możliwa do osiągnięcia. Tymczasem reforma stosunków społecznych okazywała się zadaniem syzyfowym, o czym najdobitniej świadczą proponowane rozwiązania: „rozkwit życia obywatelskiego jest niezbędną formą $\mathrm{w}$ dobie przechodzenia od upaństwowienia społeczeństwa do uspołecznienia państwa. Pragnę z całą mocą podkreślić, że wszystko, co nie jest sprzeczne $z$ wizją ładu społecznego socjalistycznego państwa, powinno znajdować w naszych instancjach przychylność i wsparcie. Otwarcie partii na inicjatywy społeczne, wspieranie ich i służenie wszelkimi środkami, które posiadamy, wzmocni nasze siły w społeczeństwie. Tego wymaga wybrana przez nas droga reform i socjalistycznej odnowy"61. Te recepty, tym razem dotyczące przestrzeni szeroko rozumianego życia społecznego, dopełniają obrazu gorączkowych poszukiwań „nowego socjalizmu”.

$\mathrm{Na}$ ile jednak pomysły te można uznać za rzeczywiście nowe? Ich bliższa analiza pokazuje, że w gruncie rzeczy sprowadzały się one do wycofania się państwa $z$ dyrektywnego regulowania życia społecznego. Innymi słowy, ich nowatorstwo sprowadzało się do poważnego poszerzenia nisz wolności: być może do tego stopnia, że można byłoby już mówić nie o niszach, ale znacznie szerszych enklawach wolnej aktywności. Stanowiło to jednak intelektualną kalkę rozwiązań - o ironio! - z lat sześćdziesiątych właśnie. Oto bowiem, de facto, proponowano wskrzeszenie formuły Jánosa Kádára z 1962 („,aki nincs ellenünk, az velünk van" - kto nie przeciwko nam, ten z nami). I chociaż sam Miller chciał widzieć $\mathrm{w}$ tej propozycji nadzieję na wskrzeszenie nastrojów twórczego fermentu i buntu, to było w tym myślenie życzeniowe. Poddawali się mu zwłaszcza ci, którzy uważali, że tak ograniczone koncesje będą w stanie zmienić nastrój głębokiej apatii, w jakim znajdowali się Polacy u schyłku lat osiemdziesiątych ${ }^{62}$.

„Trzeba nam proponować, stymulować, zachęcać, narzucać styl, nawet modę na życie niespokojne, na życie buntownicze, burzące skostniałości, zatrzymujące

${ }^{59}$ AAN, KC PZPR, III/190, Stenogram II części X Plenum KC PZPR, 16-18 I 1989, k. 188.

${ }^{60} \mathrm{~J}$. Bockman, Markets in the Name of Socialism. The Left-Wing Origins of Neoliberalism, Stanford 2011, s. 180-181.

${ }^{61}$ AAN, KC PZPR, III/190, Stenogram II części X Plenum KC PZPR, 16-18 I 1989, k. 190.

${ }^{62}$ M. Przeperski, Sytuacja nierewolucyjna. Polacy u progu obrad Okrągłego Stołu, „Więż” 2019, nr 1, s. $92-108$. 
czas w drodze do nowoczesnej przyszłości”63 - przedstawiał Miller swoje pomysły na dotarcie do polskiej młodzieży. Tymczasem polska młodzież była najbardziej kontestacyjnie nastawioną cząstką polskiego społeczeństwa. Dylemat tego, jak wyrwać młodzież z zaklętego kręgu postaw opozycyjnych, nie został przez komunistów rozstrzygnięty przed upadkiem systemu. Musiała ona poszukać sobie miejsca w warunkach rynkowej wolnej amerykanki, jaka zapanowała po $1990 \mathrm{r}$. Ograniczone pomysły społecznego otwarcia zostały zbojkotowane przez młodsze pokolenia.

\section{Próba konkluzji}

Badania, których fragment przedstawiłem w powyższym tekście, prowadzą w moim przekonaniu do trzech zasadniczych wniosków.

Po pierwsze, leninizm praktykowany tak w Polsce, jak i na Węgrzech w paradoksalny sposób utorował drogę do wolnego rynku, bo gospodarka komunistyczna się załamała, praktyka komunistyczna - sensu largo - zniosła politykę, w jej miejsce wprowadziła wiarę oraz zarządzanie (a z czasem pozostało jedynie to drugie). Trwałą pozostałością leninizmu był radykalizm i gotowość do przyjmowania nowych utopii - tym razem np. neoliberalnych, a w każdym razie wolnorynkowych. W tym również koncepcję „społeczeństwa obywatelskiego”, którą można interpretować jako demokratyczno-liberalną utopię.

Po drugie, przemiany myślenia w partiach komunistycznych na poziomie elit są ważne i niewątpliwie miały wpływ na ostateczną drogę, którą potoczyły się wydarzenia w Polsce i na Węgrzech. Dobrze jednak na tym nie poprzestawać, lecz także zakreślić badania szerzej, przyglądając się zmianom mentalności, ale i poglądów i codziennych nastawień, na poziomie aparatu, szeregowych członków partii, a w końcu na poziomie interakcji pomiędzy elitami władzy a społeczeństwem. Ważnym tropem wydaje się tu gotowość Polaków do akceptacji skrajnie liberalnej wersji wolnego rynku wykazywana przez badania sondażowe począwszy od roku $1983^{64}$.

Wreszcie, koniec lat osiemdziesiątych to kres kształtowania się „modelu chińskiego". Wydawał się on przez długi czas panaceum na kryzys realnego socjalizmu, zdając się obiecywać możliwość pogodzenia ze sobą na poziomie praktyki politycznej najbardziej nieprawdopodobnych elementów, takich jak wolność i nie-wolność w ramach jednego organizmu państwowego. Wolnorynkowy leninizm nie był - gdyby spojrzeć na to z tej perspektywy - rzeczą uważaną za niemożliwą do realizacji. Nie powiódł się przede wszystkim dlatego, że jak samospełniająca

${ }^{63}$ AAN, KC PZPR, III/190, Stenogram II części X Plenum KC PZPR, 16-18 I 1989, k. 193.

${ }^{64}$ M. Marody, Dylematy postaw politycznych i orientacji światopoglądowych, w: Oswajanie wielkiej zmiany. Instytut Socjologii UW o polskiej transformacji, red. I. Krzemiński, J. Raciborski, Warszawa 2007, s. 97. 
się przepowiednia zadziałało thatcherowskie hasło there is no alternative. Jak się okazało, jednymi z najgorliwszych brokerów tego hasła stali się paradoksalnie prominentni funkcjonariusze partii komunistycznych, tacy jak Németh czy Miller.

\section{Inventing Free-Market Leninism. Dilemmas of the Last Generation of Communists in Hungary and Poland (Summary)}

Poland and Hungary are interesting units for a comparative study on the last years of the communist system. Both countries faced similar problems and tried to solve them similarly. Perhaps the most crucial issue was to reform the economic system and build an efficient free-market economy integrated with global circulation. Miklós Németh and Leszek Miller held the most important positions in the political hierarchy in both countries. They used a language that, on the one hand, expressed their political intentions, while on the other shaped political reality. It is evident that both reformers of communism did not hesitate to reach for surprisingly liberal means, both on the economic and social levels. However, they were paradoxically extracted from the tradition of reforms (more broadly: changes) in socialism understood as a complex institutional system. It remains a challenge for further research to discover and analyse the sources of such attitudes and such actions.

\section{Bibliografia}

\section{Edycje źródłowe}

Balcerowicz L., Trzeba się bić z PiS o Polskę, Warszawa 2016

Gorbaczow M., Przebudowa i nowe myślenie dla naszego kraju i dla całego świata, przeł. A. Karkus et al., Warszawa 1988

Miller L., Anatomia sity. Rozmowa z Robertem Krasowskim, Warszawa 2013

Oplatka A., Németh Miklós - Mert ez az ország érdeke, Budapest 2014

Polska 1986-1989. Koniec systemu, t. 2: Dyskusja, red. A. Paczkowski, Warszawa 2002

Rakowski M.F., Dzienniki polityczne 1987-1990, Warszawa 2005

Wiśniewski W., Dlaczego upadł socjalizm? Od straszności do śmieszności, Toruń 2015

\section{Opracowania}

Antal A., Chicago a Dimitrov téren. Neoliberalizmus és a Kádár-rendszer, Budapest 2021

Bockman J., Markets in the Name of Socialism. The Left-Wing Origins of Neoliberalism, Stanford 2011

Communist Reformation. Nationalism, Internationalism, and Change in the World Communist Movement, red. G.R. Urban, New York 1979

Delsol Ch., Wprowadzenie do wydania polskiego, w: V. Tismăneanu, Diabeł w historii. Komunizm, faszyzm i inne lekcje wieku dwudziestego, wprowadzenie Ch. Delsol, przeł. K. Michałowicz, Warszawa 2018, s. 7-13

Földes G., Az eladósodás politikatörténete, 1957-1986, Budapest 1995

Grala D.T., Reformy gospodarcze w PRL (1982-1989). Próba uratowania socjalizmu, Warszawa 2005

Jowitt K., The New World Disorder. The Leninist Extinction, Berkeley 1992

Kowal P., Mit „pokojowego przekazania władzy” a polityczny plan utrzymana wplywów PZPR, w: Sprzeczne narracje... z historii powojennej Polski 1944-1989, red. R. Spałek, Warszawa 2020, s. 373-389

Leszczyński A., Skok w nowoczesność. Polityka wzrostu w krajach peryferyjnych 1943-1980, Warszawa 2013 
Marody M., Dylematy postaw politycznych i orientacji światopoglądowych, w: Oswajanie wielkiej zmiany. Instytut Socjologii UW o polskiej transformacji, red. I. Krzemiński, J. Raciborski, Warszawa 2007, s. $92-110$

Mark J., Iacob B.C., Rupprecht T., Spaskovska L., 1989: A Global History of Eastern Europe, Oxford 2019

Mitrovits M., Az önigazgatás bukása. A neoliberális rendszerváltás Lengyelországban, „Eszmélet”, 2009, nr 83, s. 33-53

Nałęcz D. i T., 1989-1990. Czas przełomu, Warszawa 2019

Krzemiński I., System społeczny „epoki gierkowskiej”, w: Społeczeństwo polskie w kryzysie, red. S. Nowak, Warszawa 2004, s. 95-134

Ost D., Solidarność a polityka antypolityki, przeł. S. Kowalski, Gdańsk 2014

Przeperski M., Historia pewnego przystosowania. Węgrzy lat sześćdziesiątych w raportach Departamentu Badania Słuchalności Radia Wolna Europa, w: Opozycja i opór społeczny w Polsce po 1956 roku, red. J. Olaszek, T. Kozłowski, Warszawa 2011, s. 219-239

Przeperski M., Sytuacja nierewolucyjna. Polacy u progu obrad Okragłego Stołu, „Więź” 2019, nr 1, s. $92-108$

Rainer J.M., János Kádár (1912-1989). Der letzte Generalsekretär der ungarischen Kommunisten, w: Die letzten Generalsekretäre Kommunistische Herrschaft im Spätsozialismus, red. M. Sabrow, S. Schattenberg, Berlin 2018, s. 65-90

Ripp Z., Rendszerváltás Magyarországon 1987-1990, Budapest 2006

Staniszkis J., Postkomunizm. Próba opisu, Gdańsk 2001

Szacki J., Liberalizm po komunizmie, Kraków 1994

Targalski J., Służby specjalne i pieriestrojka. Rola służb specjalnych $i$ ich agentur $w$ pieriestrojce $i$ demontażu komunizmu w Europie sowieckiej, t. 1-5, Warszawa 2017

Taubman W., Gorbachev. His Life and Times, New York 2017

Tismaneanu V., Wizje zbawienia. Demokracja, nacjonalizm i mit w postkomunistycznej Europie, przeł. H. Janowska, Warszawa 2000

Tökés R.L., Hungary's Negotiated Revolution. Economic Reform, Social Change and Political Succession, Cambridge 1996

Wciślik P., „Totalitarianism” and the Limits of Polish Dissident Political Thought. Late Socialistm and After, w: Thinking Through Transition. Liberal Democracy, Authoritarian Past, and Intellectual History in East Central Europe After 1989, red. M. Kopeček, P. Wciślik, Budapest 2015, s. 73-108

Zaremba M., Komunizm, legitymizacja, nacjonalizm. Nacjonalistyczna legitymizacja władzy komunistycznej $w$ Polsce 1944-1980, Warszawa 2005

Zybertowicz A., W uścisku tajnych służb. Upadek komunizmu i układ postnomenklaturowy, Komorów 1993

Michał Przeperski (ur. 1986), doktor historii, pracownik Instytutu Historii Nauki PAN, specjalizuje się w dziejach Europy Środkowej w XX w. Ukończył studia historyczne i prawnicze na Uniwersytecie Warszawskim, studiował też historię na Central European University w Budapeszcie. Autor książek Gorące lata trzydzieste. Wydarzenia, które wstrząsnęły Rzeczpospolita (2014), Nieznośny ciężar braterstwa. Konflikty polsko-czeskie w XX wieku (2016) i Mieczysław F. Rakowski. Biografia polityczna (2021). Laureat nagrody „Nowych Książek” dla najlepszej książki roku (2017), Nagrody Naukowej tygodnika „Polityka” (2021), Nagrody Specjalnej Fundacji Identitas (2021) oraz Nagrody KLIO (2021).

Kontakt: michal.przeperski@ihnpan.pl 